\title{
Habitat Correlates of the Southern Torrent Salamander, Rhyacotriton variegatus (Caudata: Rhyacotritonidae), in Northwestern California'
}

\author{
HARTWELL H. WELSH, JR. AND A MY J. LIND \\ Pacific Southwest Research Station, USDA Forest Service \\ 1700 Bayview Dr., A rcata, California 95521, U SA
}

ABSTRACT. -A systematic stratified sampling design was used to quantify the habitat relationships of the southern torrent salamander, Rhyacotriton variegatus, in northwestern California. We sampled 53 first to third order streams, each surrounded by at least 5-7 ha of relatively homogeneous forest or harvested forest habitat. Measurements of $\mathbf{1 2 1}$ attributes of the forest and stream environment were recorded in conjunction with area-constrained aquatic sampling for salamanders. A subset of 68 variables, grouped into 11 ecological components including attributes at the landscape, macrohabitat, and microhabitat scales, was used in a hierarchical analysis of habitat associations. Results from discriminant and regression analyses indicated that this species occurs within a relatively narrow range of physical and microclimatic conditions and is associated with cold, clear headwater to low-order streams with loose, coarse substrates (low sedimentation), in humid forest habitats with large conifers, abundant moss, and $>\mathbf{8 0} \%$ canopy closure. Thus, the southern torrent salamander demonstrates an ecological dependence on conditions of microclimate and habitat structure that are typically best created, stabilized, and maintained within late seral forests in northwestern California.

The southern torrent salamander (Rhyacotriton variegatus) (previously R. olympicus variegatus) is the southernmost member of the family 'Rhyacotritonidae, comprised of a single genus with four species endemic to the Pacific Northwest (Good and Wake, 1992). Rhyacotriton variegatus occurs in aquatic habitats in coniferdominated forests at elevations below $1469 \mathrm{~m}$ (L. Diller, pers. comm.) in the coast ranges from Mendocino County, California to the Little Nestucca River and Grande Ronde Valley of northwestern Oregon (Nussbaum et al., 1983; Stebbins, 1985; Good and Wake, 1992; Leonard et al., 1993). Welsh and Lind (1992) examined the

'This article was written and prepared by U.S. Government employees on official time, and it is therefore in the public domain and not subject to copyright. metapopulation structure of $\mathrm{R}$. variegatus in northwestern California and estimated the species occurs in isolated sub-units at a frequency of 0.07 populations per $\mathrm{km}$.

Few quantitative data exist on the habitat affinities of R . variegatus (see Corn and Bury, 1989; Bury et al., 1991). A necdotal and general accounts indicate that $R$. variegutus occur in springs, seeps, small streams, and margins of larger streams. They avoid open water and seek the cover of moss, rocks, and organic debris in shallow, cold, percolating water (Anderson, 1968; Nussbaum and Tait, 1977; Nussbaum et al., 1983; Stebbins, 1985; Bury, 1988; Bury and Corn, 1988; Corn and Bury, 1989; Welsh, 1990; Bury et al., 1991; Good and Wake, 1992; Leonard et al., 1993). Substrate conditions described for this species consist of water flowing through gravel, pebble, and cobble with little fine sediment. Habitat use differs slightly between the adult and larval life 
stages of R. variegatus. The larvae are entirely aquatic. Adults, although primarily aquatic, will occasionally use adjacent moist riparian and forest microhabitats in the wet season (pers. obs.).

Recent research in northwestern California revealed that $R$. variegatus was found at significantly more sites in late seral forests (oldgrowth) than in early seral stages (Welsh and Lind, 1988; Welsh, 1990), but the number of sites sampled was small and these results require confirmation. Corn and Bury (1989) reported higher densities and biomass of this salamander in streams in uncut forests compared with logged forests in western Oregon.

Rhyacotriton variegatus has a naturally patchy distribution in northwest\&n California, showing a strict association with headwaters and low order tributaries (Welsh and Lind, 1988, 1992). This salamander is a State "species of special concern" (Jennings and Hayes, 1994) due to the following factors: (1) distributional limits imposed by this habitat specificity; (2) an unusually high degree of genetic heterogeneity among sub-populations (Good and Wake, 1992); (3) the apparent association of this species with late seral attributes; and (4) the rapid loss of late seral forests due to timber harvesting (Thomas et al., 1988). A petition recently accepted by the U.S. Fish and Wildlife Service for listing R. variegatus as threatened under the Endangered Species Act, cites these same factors (Federal Register, 1995). A better understanding of the habitat relationships of this salamander might explain their absence or lower abundance in early seral forests and provide a basis for management alternatives that could reverse the reduction in its numbers due to forestry practices.

The objectives of our study were: (1) to examine and quantify the habitat associations of $R$. variegatus at multiple spatial scales throughout the mixed conifer-hardwood forests of northwestern California; (2) to clarify the nature of the apparent relationship with forest -succession; and by meeting the first two objectives, to (3) provide information critical for evaluating the potential impacts of continued habitat alterations on this species.

\section{MATERIALS AND METHODS}

The general sampling design and the strategy of analysis used here have previously been described (Welsh and Lind, 1995). However, this study differs considerably from our earlier work in the details of both sampling and analysis. Here we provide a general outline of methods, with particular emphasis on those details that pertain to our study of R. variegatus. While this research is exploratory and correlative, and not designed to demonstrate cause and effect, such an approach is vital for developing testable hy- potheses, and can, by itself, produce strong and useful inferences about real habitat relationships (see controlled experience studies; Waters and Erman, 1990).

Site Selection .-Sites were distributed systematically across the range of $R$. variegatus within northwestern California using a stratified design, with a random component, at four nested levels: (1) biogeographic, (2) geographic (tow n ship and section), (3) seral stage, and (4) minimum essential microhabitat.

Level one was defined by the known range of the species in California based on published accounts (Stebbins, 1985) and included portions of two bioregions: the N orth Coast and Klamath (Welsh, 1994). Levels two and three consisted of systematic selection of alternating townships, randomly choosing sections therein, and selection of forest stands in from one to four seral stages within each section. These criteria were instituted across most of the range described at level one, and up to $1115 \mathrm{~m}$ based on elevational limits known to us at the time (1989) (Stebbins, 1985; unpubl. data). All sampling occurred on public lands (state and federal parks and Forest Service) within the drainages of the Smith, Klamath, Trinity, Mad and Van Duzen Rivers of the Siskiyou, Klamath, and Coast Range Mountains. Sites occurred from near the Oregon border as far south as southern Humboldt and Trinity counties, California (latitude $40^{\circ} 22^{\prime}$ ), and east from the Pacific Ocean to western Siskiyou and western Trinity counties (longitude $123^{\circ} 25^{\prime}$ ). We sampled in mixed conifer-hardwood forests dominated by Douglas-fir (Pseudotsuga menziesii) and redwood (Sequoia sempervirens). We used forest age (the mean of three corings from the dominant size class of conifers) to represent seral stage. Up to four stands were selected in each section when available (one each clearcut [0-30 yr], young [31-99], mature [100-200], and old-growth [+200]). Stand ages sampled ranged from one year old clearcuts to a 941 yr old redwood stand. Sampling sites were located in at least 5-7 ha of contiguous forest or clearcut (no edge habitat) with uniform forest structure and tree species composition (relatively homogeneous stands).

Our sampling design for R. variegatus differed from the design previously described (Welsh and Lind, 1995) primarily at the fourth level, that of selecting sites within stands with minimum essential microhabitat (MEM). The intent was to maximize time, effort, and the usefulness of data sets by not sampling for salamanders at sites with an extremely low probability of occurrence. Therefore our sampling universe at the fourth level was limited to first to third order streams. An acceptable site had to contain at least $10 \mathrm{~m}^{2}$ of perennial aquatic habitat in a 
natural watercourse. This $10 \mathrm{~m}^{2}$ could be any configuration of seep, spring, or stream channel, but the entire area had to consist of aquatic microhabitat. We used two hydrophilic plant species (California spikenard [A ralia californicus] and chain fern [Woodwardia firmbriata]), or the presence of populations of macroinvertebrates such as stoneflies (order Plecoptera) and Dobson fly larvae (Corydalus sp.), as evidence of perennial water. Final site placement was determined by the most direct approach from the nearest trail or road access. All sites were located at least $75 \mathrm{~m}$ from any high contrast forest edge. We selected sites with a variety of stream microhabitats (McCain et al., 1990) but avoided centering the $10 \mathrm{~m}^{2}$ sites on deep pools or high gradient/ discharge habitats (e.g., waterfalls or cascades) because the use of such habitats by Rhyucotriton conflicted with literature accounts. However, these microhabitat types did occur peripherally at many sites and were sampled and included in our analysis.

A nimal Sampling. -Fixed area aquatic searches (Welsh, 1987; Bury and Corn, 1991) (see also quadrat sampling [Jaeger and Inger, 1994]) were conducted during daylight at each site to determine numbers of animals present. All but two sites were sampled during the summer (June to October) of 1989 to minimize seasonal effects. One or two searchers worked side by side to thoroughly search a $10 \mathrm{~m}^{2}$ plot. Each plot was systematically searched, from downstream up, with all pebbles, cobbles, and boulders turned and finer substrates carefully hand sifted down to the armoured streambed or to a depth of 15 $\mathrm{cm}$, unless we saw a salamander escape deeper, in which case we pursued it. We captured both larvae and adults. We assume our capture rates are correlated to absolute densities and provide us relative densities that are valid for comparing $R$. variegatus numbers amoung sites.

$M$ easuring Biotic and Abiotic Parameters.-We selected habitat variables for measurement using three. criteria: (1) parameters that reflected structural, compositional, and microdimatic aspects of the forest and stream environment relevant to R. variegatus as indicated by previous research; (2) parameters that would indicate change in structure and composition of the forest resulting from common management practices such as timber harvesting and reforestation, or natural successional events such as fire, landslide, or flood; and (3) variables that incorporated aspects of the forest and stream environment reflecting three scales of spatial organization: landscape, macrohabitat, and microhabitat.

Our approach was to initially estimate a wide range of parameters, and then eliminate highly redundant variables using correlation analysis prior to multivariate analyses. Variables with a high number of zero values across sites $(\geq 70 \%)$ were also removed because they could not be normalized, and we believe that they were not likely to affect salamander distribution or abundance. Initial measurements of general locator variables (landscape scale), forest structure (macrohabitat scale), and microhabitat variables, resulted in a total of 121 variables (see Welsh [1993] for the complete list and details on measurements). Aquatic microhabitat categories followed McCain et al. (1990) except we combined all pool types into two categories and defined two additional categories: seep and splash zone (Table 1). Seeps were defined as shallow $(<2 \mathrm{~mm})$, slow-flowing water through rock substrates; splash zones were defined as wetted areas with no measureable flow or depth. Aquatic substrate composition was characterized in two ways: (1) as a visual estimate of the percent of the search area in ten substrate categories (e.g., gravel, pebble, cobble; sizes follow Platts et al., 1983); and (2) as a percent of a 4000 cm3 sample of streambed substrate, taken from a representative site just above each $10 \mathrm{~m}^{2}$ search area, dried, sifted into five size classes and weighed (listed by actual size, see Table 1). We performed preliminary descriptive analyses to assess the normality of the distributions of all variables, and deviations were corrected by appropriate transformations (Sokal and Rohlf, 1981). Variable reduction procedures resulted in 68 independent variables for our multivariate analyses (Table 1).

Statistical Analyses.-We employed discriminant analysis and regression for statistical analyses. Used together, these techniques can reveal aspects of the habitat that may be limiting for a species and also indicate those aspects that might be managed to maintain or increase animal numbers (this complimentary approach is discussed in more detail by Welsh and Lind [1995]). Life stages were combined for both analyses. In our multivariate analyses we assumed that univariate normality implied multivariate normality (we did not test multivariate normality directly).

For the multivariate analyses we grouped variables into ecologically meaningful subsets (ecological components) on the basis of similarity of spatial scale and vertical stratum of the forest environment (Table 1) (cf. Bingham and Sawyer, 1991; Welsh and Lind, 1995). We then ran separate analyses on each component. This approach is a biologically sound and methodologically valid way to increase the sample size to variables ratio, which promotes a more substantive analysis when dealing with a large number of independent variables (James and McCulloch, 1990). 
TABLE 1. Hierarchical arrangement' of ecological components (see text) represented by 68 measurements of the forest and stream environment taken in conjunction with sampling for the southern torrent salamander (R hyacotriton variegatus).

1/ Spatial scales are in descending order from coarse to fine resolution (see Wiens, 1989). Level I relationships (biogeographic scale) were not analyzed be cause all sampling was within the species range.

2/ $\mathrm{C}=$ count variabie which is numbers per hectare; $\mathrm{B}=$ Braun-Blanquet (1932) variable which is \% cover in 0.1 ha circle; $\mathrm{L}=$ Line transect variable which is percent of $50 \mathrm{~m}$ line transect; $\mathrm{P}=\%$ of $10^{2} \mathrm{~m}$ salamander search area. Small trees $=12-53 \mathrm{~cm}$ DBH (diameter at breast height), large trees $\geq 53 \mathrm{~cm} \mathrm{DBH}$.

$3 /$ Based on mean of cores from three trees in dominant size class on site; classes used $=12-27 \mathrm{~cm}, 27-$ $53 \mathrm{~cm}, 53-90 \mathrm{~cm}, 90-120 \mathrm{~cm}$, and $+120 \mathrm{~cm}$ DBH.

4/ Solar index is an estimate of annual incident solar radiation based on latitude, slope, and aspect (Frank and Lee, 1966).

5/ Particle sizes from Platts et al. (1983); as a percent of sample (see text for procedure).

* Variable was transformed for statistical analyses.

II. Landscape Scale

A. Geographic relationships

Latitude (degrees)

Longitude (degrees)

Elevation $(\mathrm{m})$

Slope (\%)

Aspect (degrees)

III. Macrohabitat or Stand Scale

A. Trees: density by size

Small conifers-C*

*Small hardwoods-c

Large conifers- $C$

*Large hardwoods-c

Forest age (years) ${ }^{3}$

B. Dead \& down wood: surface area $\&$ counts

Logs- $B$

*Stumps-B

All logs decay-C

*All logs sound-C

C. Shrub \& understory composition $(>0.5 \mathrm{~m})$

'Understory conifer-L

Understory hardwood--L

*Large shrub-L

Small shrub L

Height II vegetation_B $(0.5-2 \mathrm{~m})$

*Bole-L

D. Ground-level vegetation $(\lessdot 0.5 \mathrm{~m})$

- Fern L

$* \mathrm{H}$ er $\bar{b}-\mathrm{L}$

*Grass L

Height I vegetation-B (O-O.5 m)

E. Ground Cover

Litter depth (cm)

'Exposed soil_B
TABle 1. Continued.
'Lichen-B

*M oss-L

*Leaf-L

*A quatic habitat-I

Dominant Rock B

*Co-dominant Rock B

F. Forest Climate

Soil temperature

Air temperature

Relative humidity

Solar index'

\% canopy closed

Soil relative humidity

IV. Microhabitat Scale

A. Aquatic habitats

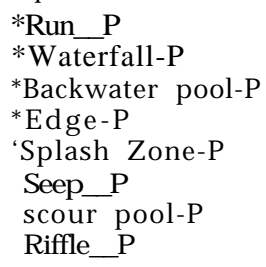

B. Coarse aquatic substrates ${ }^{5}$

Sediment 2-16 mm

Sediment 16-32 mm

"Gravel

Pebble-P

*Cobble-P

*Boulder-P

Decayed vegetation- $P$

C. Fine aquatic substrates 5

*Sediment $<0.063 \mathrm{~mm}$

*Sediment 0.063-0.5 mm

Sediment $0.5-2.0 \mathrm{~mm}$

*Silt-P

*Sand-P

'Non-filamentous algae_ $\mathrm{P}$

Cemented-P

*Detritus-P

D. Aquatic conditions

Water $\mathrm{pH}$

Water temperature

'Discharge $(\mathrm{cm} / \mathrm{sec})$

*Mean channel width

*Mean channel depth

*\%Canopy (over stream)

*Number of Dicamptodon

A two-group discriminant analysis (DA) (SAS Institute, 1990) was performed for each ecological component (Table 1) using a stepwise procedure to select variables. We tested the null hypothesis that a given variable does not add any additional discriminatory power. For model-building, a variable was entered if its $P$ value for the partial $F$ statistic was 10.10. This moderate alpha-level reduces the chance of type II errors and is more appropriate for detecting ecological trends (Toft, 1991). A linear discrim- 
inant function was then determined based on the variables selected. Welsh and Lind (1995) detail the method used for testing the assumption of homogeneity of variance-covariance structure among groups required for DA, and detail the logic for presenting all results here in the form of linear functions only.

Resulting models were then tested at alpha $\leq 0.05$ using a jackknife procedure (SAS Institute, 1990) to evaluate classification success. Cohen's Kappa (Titus et al., 1984) was computed for each test to indicate classification success compared with chance. In classification tests based on the discriminant functions, we assumed our random systematic site selection procedure yielded a proportion of sites with and without salamanders that reflects the true proportion. Therefore we adjusted the prior probabilities of group membership accordingly (priors proportional) (SAS Institute, 1990).

We performed an 'all-possible-subsets' regression analysis (APS) of each microhabitatscale ecological component (Table 1). This was followed by an APS on the combination of variables derived from the individual microhabitat components to derive a composite model. We used only sites with salamanders for these analyses. Our logic here was that given their small size, low vagility, and extreme philopatry, it would probably be variation at the microhabitat-scale that would yield the most information about habitat aspects that influence differences in numbers of $R$. variegatus. The al pha level was set at $\leq 0.05$. We also used regression in an exploratory mode to examine relationships in our data. Selected variables derived from the DA or APS were examined using simple linear and standard non-linear (logarithmic, exponential, and second order polynomial) curve-fitting. In the regression analyses those variables with the best $\mathrm{R}^{2}$ (smallest mean square error) were reported and discussed.

\section{RESULTS}

We sampled 53 sites for R hyacotriton variegatus (see map in Welsh and Lind, 1992). Thirty-three sites had salamanders, with a total of 208 captures (173 larvae and 35 adults). Densities at these sites ranged from one to 50 animals in 10 $\mathrm{m}^{2}$, with a mean of $0.68 / \mathrm{m}^{2}(\mathrm{SD}=0.89)$.

$D$ iscriminunt A nalyses. -Discriminant analyses of 11 ecological components (Table 1) yielded significant results for eight of 11 sets of variables (Table 2). Elevation was the only landscape-scale variable that discriminated between sites with and without salamanders (Table 2); with sites supporting salamanders more common at lower elevations. Jackknife results for this model were poor (only $56.6 \%$ correct) indicating that it failed to discriminate between sites at a rate much better than chance.

Five of six components at the macrohabitatscal e yielded significant models: trees, dead and down wood, ground-level vegetation, ground cover, and forest climate (Table 1). These were all single variable models, with large conifers, stumps, grass, moss, and percent canopy closed each proving to be a significant indicator of whether or not R. variegatus occupied a site (Table 2). More large conifers, moss, and higher canopy closure were indicative of sites with salamanders, while more grass and stumps were indicative of sites without salamanders; classification success results were significantly better

TABLE 2. Two-group stepwise discriminant analyses of 53 sites $^{1}$ sampled for the southern torrent salamander (Rhyacotriton variegatus) across its range in northwestern California. Independent variables were grouped for separate analyses by ecological component (Table 1). M odels were tested for classification success (\% correct) with a jackknife procedure; $P$ values indicate the classification success of each model compared with chance based on Cohen's Kappa statistic (Titus et al., 1984).

1 Missing values for $\mathbf{3}$ sites resulted in a sample size of $\mathbf{5 0}$ for the calculations of models at the microhabitat scale. - Indicates a model with heterogeneous variance-covariance matrices.

\begin{tabular}{|c|c|c|c|c|}
\hline Scale & $\begin{array}{c}\text { Model } \\
\text { variable(s) }\end{array}$ & $\begin{array}{c}\text { Model } \\
\text { P }\end{array}$ & $\begin{array}{c}\text { Model } \\
\text { jackknife score } \\
\% \text { ( } \mathbf{P} \text { value) }\end{array}$ & $\begin{array}{c}\text { Mean } \\
\text { greater for } \\
\text { sites with } \\
\text { salaman- } \\
\text { ders }\end{array}$ \\
\hline $\begin{array}{l}\text { Landscape: } \\
\text { M acrohabitat: }\end{array}$ & $\begin{array}{l}\text { Elevation } \\
\text { Large conifers: } \\
\text { Stumps } \\
\text { Grass. } \\
\text { M oss } \\
\% \text { canopy closed* } \\
\text { Splash zone* } \\
\text { Cobble } \\
\text { Sediment }<0.063 \mathrm{~mm} \text { and \% cemented }\end{array}$ & $\begin{array}{l}0.03 \\
0.002 \\
0.009 \\
0.0001 \\
0.0017 \\
0.015 \\
0.053 \\
0.044 \\
0.02\end{array}$ & $\begin{array}{l}56.6(0.48) \\
75.5(0.0003) \\
67.9(0.043) \\
79.3(0.0002) \\
62.3(0.139) \\
69.8(0.048) \\
62.0(0.50) \\
65.4(0.17) \\
69.3(0.035)\end{array}$ & $\begin{array}{l}\text { no } \\
\text { yes } \\
\text { no } \\
\text { no } \\
\text { Yes } \\
\text { Yes } \\
\text { Yes } \\
\text { Yes } \\
\text { no }\end{array}$ \\
\hline
\end{tabular}


TABLB 3. Multiple component discriminant model. All variables derived from the analyses of the ecological components (Table 2) were combined in a two-group discriminant analysis (across all scales and ecological components) to derive a multiple component model of the habitat of the southern torrent salamander. Standardized structure coefficients indicate the relative contribution of each variable to the discriminant function (Rencher, 1992); signs are opposite to that of the true relationship between salamander presence and a particular variable. This model has heterogeneous variance-covariance matrices.

\begin{tabular}{clcrr}
\hline \hline Step & \multicolumn{1}{c}{ Variable } & F-Statistic & P & $\begin{array}{c}\text { Standardized } \\
\text { structure } \\
\text { coefficient }\end{array}$ \\
\hline 1 & \% grass & 27.23 & 0.0001 & 0.670 \\
2 & Large conifers & 6.88 & 0.0117 & -0.442 \\
3 & \% cemented & 4.63 & 0.0367 & 0.666 \\
4 & \% sediment <0.063 m & 3.08 & 0.0861 & -0.461 \\
5 & Elevation & 4.95 & 0.0313 & 0.410 \\
& Splash zone & & & \\
& \% čanopy closed & & & \\
& Moss & & &
\end{tabular}

Wilks Lambda $=0.425 ; \mathrm{F}(\mathrm{df}=5,44)=11.88 ; \mathrm{P}=0.0001$

Jackknife success $(\%)=80.80$; Cohen's Kappa $=0.567 ; \mathrm{P}=0.0001$

than chance for all but the ground cover model (moss) (Table 2).

Three of four ecological components at the microhabitat-scale (Table 1) produced significant models: aquatic microhabitats, coarse aquatic substrates and fine aquatic substrates (Table 2). The aquatic microhabitat model consisting of the variable "splash zone", indicated more of this microhabitat occurred where salamanders were present. This model, however, was not a good indicator of presence based on the classification test, with results no better than chance. The coarse substrates model consisted of the variable cobble, indicating sites with a greater percent of this substrate size were more likely to contain Rhyacotriton. This model had a jackknife success of $65.4 \%$, not significantly better than chance (Table 2). The fine substrates model, the only model in the DA to contain more than a single variable, consisted of sediment $<0.063 \mathrm{~mm}$ and percent cemented (Table 2). This model indicated that sites with salamanders contained greater amounts of the very finest sediments (comprised primarily of organic material), and lower substrate cementedness. Jackknife classification for this model was $69.2 \%$, significantly better than chance.

The DA of the 10 variables from the significant component models yielded a composite model with five variables, representing three spatial scales, and four ecological components (Table 3, Fig. 1): percent grass, large conifers, percent cemented, percent sediment $<0.063$ $\mathrm{mm}$, and elevation. Classification success for this model was $80.8 \%$, significantly better than chance (Table 3 ).

Regression Analyses. - Although ten of 68 habitat variables were useful predictors of the pres- ence of $R$. variegatus (as seen by DA), regression analyses revealed that these same variables were generally not good predictors of variation in salamander numbers among sites. A bivariate scatterplot of one variable, canopy closure, revealed an interesting pattern. The majority of sites with salamanders were found in areas with $80 \%$ or higher of canopy closure (Fig. 2). The two outliers (Fig. 2) were cold springs (10.8 C) on clearcut sites with north-facing aspects and relatively high elevations $(884 \mathrm{~m}$ and $1029 \mathrm{~m})$. The 95\% confidence interval (C.I.) indicated that the true mean percent canopy closure for all

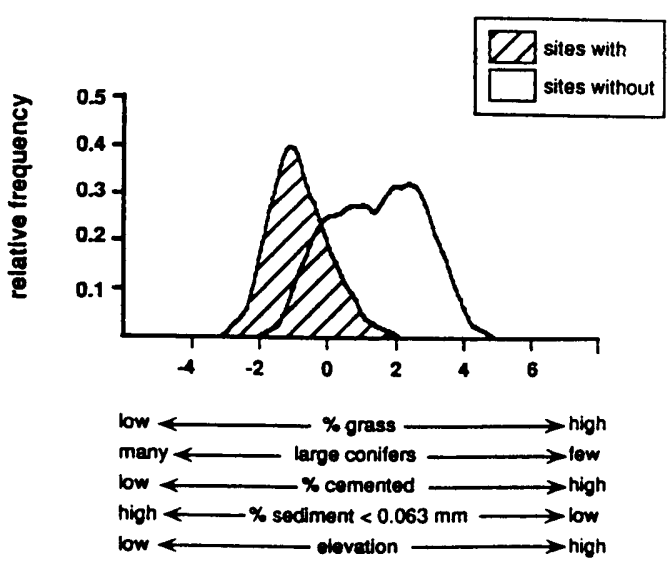

FIC. 1. Frequency curves (kernel method; Silverman [1986]) of canonical scores for sites with ( $N=$ 33 ) and without $(N=20)$ the southern torrent salamander (Rhyacotriton variegatus) based on the composite habitat model (Table 3 ). Values of variables (i.e., high or low) represent trends relative to canonical scores. 


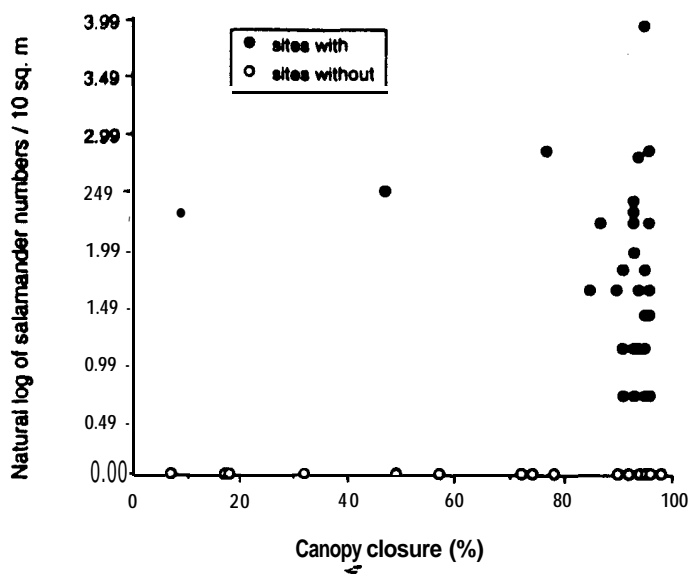

FIG. 2. Bivariate scatterplot for percent canopy closure and the natural log of southern torrent salamander (Rhyucotriton variegatus numbers/ $10 \mathrm{~m}^{2}$. Some overlapping points are obscured. sites with $\mathrm{R}$. variegatus lies between $83.2 \%$ and $94.9 \%$. The $95 \%$ C.I. for sites with no salamanders was 58.3 to $85.9 \%$ canopy closure,

APS at the microhabitat-scale produced several models with significant relationships with salamander abundance. The best single variable (with an adjusted $\mathbf{R}^{\mathbf{2}}$ of 0.331 ) was percent seep, which showed a significant positive relationship with salamander numbers (Table 4, Fig. $3 a)$. This same ecological component also produced the best multiple variable model (with an adjusted $\mathbf{R}^{\mathbf{2}}$ of 0.420 ); however, ail variables in this model (percent splash zone, percent scour pools, and percent riffles) showed negative relationships with salamander numbers (Table 4). The APS of the coarse aquatic substrates component revealed that no single coarse substrate variable alone was a good predictor of salamander numbers. However, this analysis produced a significant model with a positive slope consisting of the variables percent cobble and sediment 2.0-16 $\mathrm{mm}$ (=gravel) (Table 4). G reat

$T_{A B L E}$ 4. All-possible-subsets regressions relating microhabitat-scale ecological components (Table 1 ) to numbers of southern torrent salamanders (Rhyacotriton variegatus) using only sites with salamanders present $(\mathrm{N}=\mathbf{3 1})^{1}$. Best single variable and best model (based on highest adjusted $\mathbf{R}^{\mathbf{2}}$ ) are shown. Separate analyses were conducted on each component; variables entering each model were used to derive a final composite model. ${ }^{2}$ Standardized coefficients indicate the relative influence of each variable in the model; sign indicates the relationship with numbers of salamanders.

1 Two of 33 sites with salamanders had missing microhabitat data and could not be used in this analysis. 2 Maximum number of variables permitted in the composite model based on sample size to number of variables ratio (Johnson, 1981). 3 Standard error of the estimate.

\begin{tabular}{|c|c|c|c|c|c|c|}
\hline Ecological component & Variable or model & $\begin{array}{l}\text { Standard- } \\
\text { ized } \\
\text { coefficient }\end{array}$ & $\underset{\text { (adj. }}{\mathbf{R}^{2}}$ & $\mathrm{~F}$ & $\mathbf{P}$ & SE' \\
\hline \multicolumn{7}{|l|}{ A quatic microhabitats } \\
\hline $\begin{array}{l}\text { Best variable: } \\
\text { Best model: }\end{array}$ & $\begin{array}{l}\text { Seep } \\
\text { Splash zone } \\
\text { scout pools } \\
\text { Riffle }\end{array}$ & $\begin{array}{r}0.594 \\
-0.208 \\
-0.500 \\
-0.400\end{array}$ & 0.420 & 15.81 & 0.0004 & 0.57 \\
\hline \multicolumn{7}{|l|}{ Course aquatic substrates } \\
\hline $\begin{array}{l}\text { Best variables: } \\
\text { Best model: }\end{array}$ & $\begin{array}{l}\text { Sedmt. } 2.0-16 \mathrm{~mm} \\
\text { Sedmt. } 2.0-16 \mathrm{~mm} \\
\text { Cobble }\end{array}$ & $\begin{array}{l}0.296 \\
0.356 \\
0.353\end{array}$ & $\begin{array}{l}0.056 \\
0.104\end{array}$ & $\begin{array}{l}2.78 \\
3.98\end{array}$ & 0.029 & $\begin{array}{l}0.73 \\
0.69\end{array}$ \\
\hline $\begin{array}{l}\text { Fine aquatic substrates } \\
\text { Best variable and model: }\end{array}$ & Sand & -0.215 & 0.209 & 8.92 & 0.0057 & 0.66 \\
\hline $\begin{array}{l}\text { A quatic Conditions } \\
\text { Best variable: } \\
\text { Best model: }\end{array}$ & $\begin{array}{l}\text { Water depth } \\
\% \text { canopy closed (over stream) } \\
\text { Mean channel width } \\
\text { No. of D icamptodon }\end{array}$ & $\begin{array}{r}-0.305 \\
-0.260 \\
0.195 \\
-0.325\end{array}$ & 0.096 & 2.06 & 0.095 & 0.72 \\
\hline $\begin{array}{l}\text { Splash zone } \\
\text { Scour pool } \\
\text { Riffle } \\
\text { Sand }\end{array}$ & BEST COMPOSITE M & $\begin{array}{l}\text { DEL } \\
-0.236 \\
-0.395 \\
-0.372 \\
-0.323\end{array}$ & 0.501 & 8.54 & 0.0002 & 0.53 \\
\hline
\end{tabular}



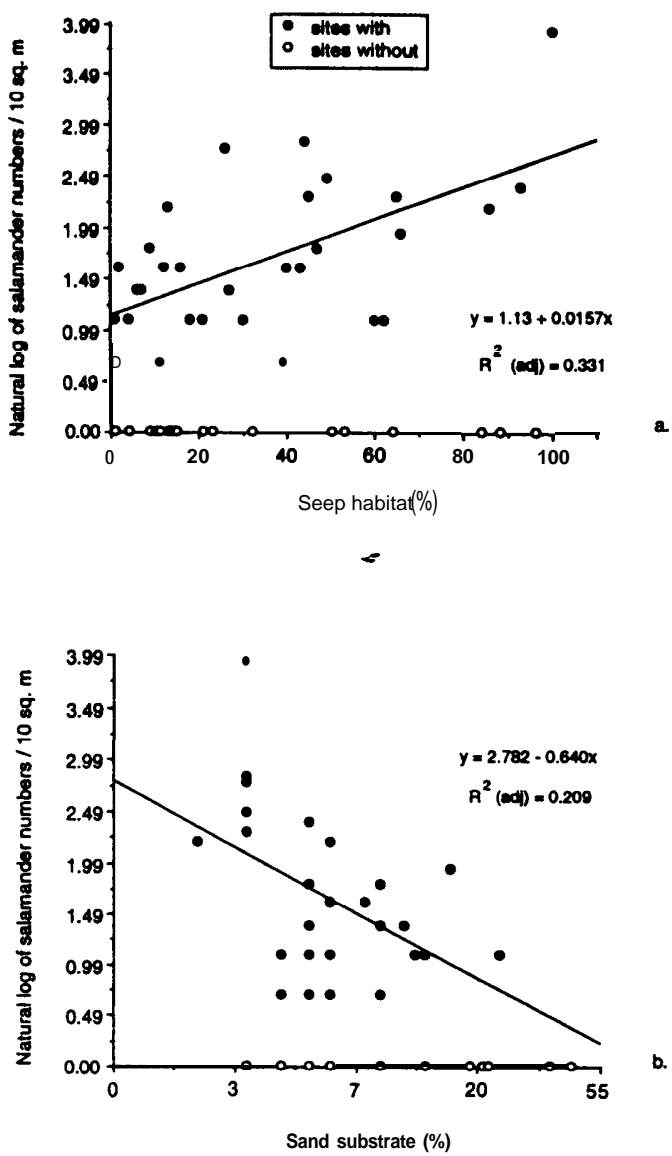

FIG. 3. Bivariate scatterplots of selected microhabitat variables (percent composition of $10 \mathrm{~m}^{2}$ sample plots) versus southern torrent salamander (R hyacotriton variegatus) numbers: a. percent seep; $b$. percent sand substrate. Regression lines and $R^{2}$ (adj.) values apply to sites with salamanders only ( $N=31)$; sites without salamanders $(\mathrm{N}=20)$ are included to show overall distribution. Salamander numbers and percent sand are natural log transformed. Some overlapping points are obscured.

er amounts of these coarse substrates were, together, a significant predictor of salamander abundance. The model derived from the fine aquatic substrates component, consisting of the single variable percent sand (with an adjusted $\mathrm{R}^{2}$ of 0.209 ), showed a significant negative relationship with salamander numbers (Table 4; Fig. 3b). The best composite model derived from the APS (with an adjusted $\mathbf{R}^{2}$ of 0.501 ) was comprised entirely of variables showing negative relationships with salamander abundance (Table 4). Three of the four variables in this model were from the aquatic microhabitats component (Table 1).
DISCUSSION

The most interesting finding of this study was that those habitat variables that were good predictors of the presence of R hyacotriton variegatus were mostly different, and often functioned at a different spatial scale, from those variables that were good predictors of variation in salamander abundance.

Landscape Scale. - At the landscape scale only elevation was a significant indicator of presence (Table 2), indicating that some attribute(s) that varies along an elevational gradient is limiting to the distribution of $R$. uariegatus populations in California.

$M$ acrohabitat Scale.-Five significant macrohabitat models provided evidence of an association of R. uariegatus with conditions characteristic of late seral forest habitats in California (Table 2). These variables were highly complementary in depicting either late seral attributes, or in the case of the two negative relationships, the absence of same. The trees component model, which indicated significantly more large conifers on sites with salamanders, provided the most direct indication of this association with late seral habitat. Forest age by itself did not prove to be a useful predictor of salamander presence because old trees are not essential for the creation of late seral habitats. Highly productive sites can produce late seral attributes earlier (with younger trees) as a result of accelerated growth. The ground cover model (more moss on sites with salamanders) indicated the presence of late seral conditions or high moisture, or both. Bingham and Sawyer (1991) reported significantly greater moss abundance in old-growth compared with young forests in northwestern California. High ground moisture is also linked with late seral forests because the more complex forest structure in such habitats helps to create and maintain it (Chen et al., 1993a). The forest climate model (\% canopy closed) also indicated an association of R. var. iegatus with canopy conditions and resulting microclimates typical of late seral sites (Table 2; Fig. 2). Open sites show a wide range of relative humidities and high mean air temperatures over time (Chen et al., 1993b). Sites with greater canopy cover, by virtue of the ameliorating effects on daily solar incidence, wind speed, and precipitation, tend to maintain cooler temperatures and higher humidity at ground level compared with sites with less canopy cover (Chen et al., 1993a). Canopy conditions in turn directly influence temperatures in associated streams, with greater canopy closure providing cooler and more stable water temperatures (Brown and Krygier, 1970; Beschta et al., 1987). Such moderated microclimatic condi- 
tions, especially in warmer parts of northwestern California at the southern end of the range of $\mathrm{R}$. variegatus, are probably a life requisite given its physiological limitations (Ray, 1958; Brattstrom, 1963).

The DA of the dead and down wood and ground-level vegetation components also indicated the importance of late seral forest structure for R. variegatus, but in a contrary fashion. These models demonstrated that higher numbers of stumps and more grass, respectively, indicated a lack of salamanders at a given site (Table 2). Stumps and grass are characteristic of open, logged or burned sites where conditions were seldom conducive to salamander survival because air and watetiemperatures were high, relative humidity low, and protective cover was usually lacking. Grass can also be abundant in drier, more open forest areas which are also usually unsuitable for this salamander because of microclimatic conditions.

While the five macrohabitat variables from the DA were good predictors of general site conditions for $R$. variegatus none was a good predictor of variation in abundance, suggesting that such variation results from changes in attributes at a finer scale of resolution. Given the extreme philopatry (Nussbaum and Tait, 1977; Welsh and Lind, 1992) and the narrow physiological limits of R. uuriegutus (Ray, 1958; Brattstrom, 1963), we believe that relationships at the microhabitat-scale are more critical to an understanding of the ecology of this species.

$M$ icrogabitat Scale-Of the four microhabitatscale variables that produced significant discriminant models (splash zone, cobble, sediment $<0.063 \mathrm{~mm}$, and percent cemented) only the fine aquatic substrates model yielded a significant classification test result (Table 2). Percent splash zone produced contradictory results between the DA and APS (Tables 2 and 4); sites with salamanders present had significantly more of this microhabitat compared to sites without salamanders, but salamander abundance varied negatively with splash zone. This outcome is probably the result of fewer captures in areas dominated by splash zone, indicating it is a microhabitat indicative of areas that support this species, but not one that they actually use often. Cobble substrate was a weak predictor in both analyses. The fine substrates DA model described two characteristics that appear to be essential for R. variegatus presence; low cementedness and fine organic material (sediment $<0.063 \mathrm{~mm}$ ) (see below).

The APS analysis proved far more informative about relationships at the microhabitat scale than did the DA. Percent seep habitat was the best single microhabitat variable for predicting salamander abundance where they did occur
(Table 4). Southern torrent salamanders, despite their name, showed a strong negative relationship with fast (riffle) or deep (scour pool) microhabitats. Diller and Wallace (1996) reported a positive relationship between salamander numbers and riffle habitat. This contrary result may derive from the fact that Diller and Wallace confined their sampling to first order streams while we sampled in first to third order streams. Riffles have different characteristics depending on stream size. This species is too small (16-52 mm SVL; Welsh and Lind, 1992) to be well suited physically for life in fast currents, and occurs primarily within the streambed substrates of shallow, slow-flowing parts of streams. The selection of shallow water also has been hypothesized as a response to predation by Pacific giant salamanders (D icamptodon ten ebrosus) (Stebbins, 1953; N ussbaum, 1969). The APS of aquatic conditions did show a weak negative relationship with $\mathrm{D}$. tenebrosus, but this model failed to meet the prescribed alpha level (Table 4). However, this relationship merits further research because $D$. tenebrosus is known to feed on R hyacotriton, and Welsh (1993) reported a significant quantitative model for $D$. tenebrosus that showed a positive association with both numbers of Rhyacotriton and numbers of larval tailed frogs (A scuphus truei).

Both the DA and APS of the coarse aquatic substrates component demonstrated positive associations with cobble-size substrates, but the DA model had poor classification success and the APS of the single variable cobble was not significant (Tables 2 and 4). These results indicated that cobble alone was not a good predictor of the presence or abundance of R. variegatus. However, the APS analysis indicated that salamander numbers were significantly greater when the coarse substrate was comprised of a combination of cobble and fine to medium gravel (sediment 2.0-16 mm; Table 4). We believe a combination of different sizes of coarse substrates provides the greatest amount and variety of interstices for foraging, while providing many smaller escape spaces for cover from potential aquatic predators.

The DA result, indicating a positive relationship with the smallest sediment class (CO.063 $\mathrm{mm}$ ) and a negative relationship with substrate cementedness, appears contradictory (Table 2). However this species' association with shallow, slower-flowing water (often occurring along stream margins where fine sediments tend to settle out) and preference for coarser substrates (which provide more exploitable interstices) re sults from its' selection of microhabitats that offer the best combination of cover and food resources. The very finest sediments are comprised of primarily organic materials that con- 
tribute to the food web in these microhabitats (Meehan et al., 1977; Meyer et al., 1988) and would support the small invertebrate prey of R. variegatus (Bury, 1970). The strong negative relationships with sand (Table 4, Fig. 3b), likely results from the fact that sand fills interstices among coarse substrate particles, increases cementedness, and eliminates essential cover (Bury, 1988; Bury and Corn, 1988; Corn and Bury, 1989).

Fine sediment effects can be less severe in high gradient stream reaches because fines tend to move through them and accumulate in lower gradient areas. While we found no relationship with stream gradient (slope), Corn and Bury (1989) and Diller and Wallace (1996) both found a positive relationship between gradient and $\mathrm{R}$. variegatus numbers. Corn and Bury noted this relationship was only true for their logged sites where fine sediments from timber harvesting appear to be flushed from high gradient reaches. All the sites sampled by Diller and Wallace were in logged areas. The higher water velocites in high gradient reaches would also tend to move the finest sediments (i.e., sediments $<0.063 \mathrm{~mm}$ ) that appear to be important to this species. Consequently, we suspect that a streambed substrate with a range of coarse particle sizes, and thus an abundance of interstices, and with a variety of flow rates (from the thalwag to the margins) through this mixture of substrates, would provide the best microhabitat for this salamander. Other studies have demonstrated the importance of increased substrate and microhabitat diversity in promoting aquatic salamander abundance (see Parker, 1991 and references therein).

The seven variables in the aquatic conditions component (Table 1) were not good predictors of salamander presence or abundance. This result was somewhat surprising since these variables included water temperature and discharge. Rhyacotriton exhibit a narrow range of Low body temperatures (Brattstrom, 1963) and critical thermal maximum (CTM) experiments indicated signs of thermal stress at $17.2 \mathrm{C}(\mathrm{Wa}-$ ters and Welsh, unpubl. data). Ail of our sites fell within a narrow range of relatively low water temperatures (Fig. 4) so no tolerance limits were discernible. N onetheless, the combined distributions of water temperatures from this and an earlier study (Welsh, unpubl. data) indicated the highest abundances of salamanders occurred in a narrow range from about 8-13 C (Fig. 4). In the case of stream discharge, the high variance both within and across groups of sites made it impossible to sort out a preferred range of values. This is, to a large degree, a problem of a lack of instrumentation for measuring wa-

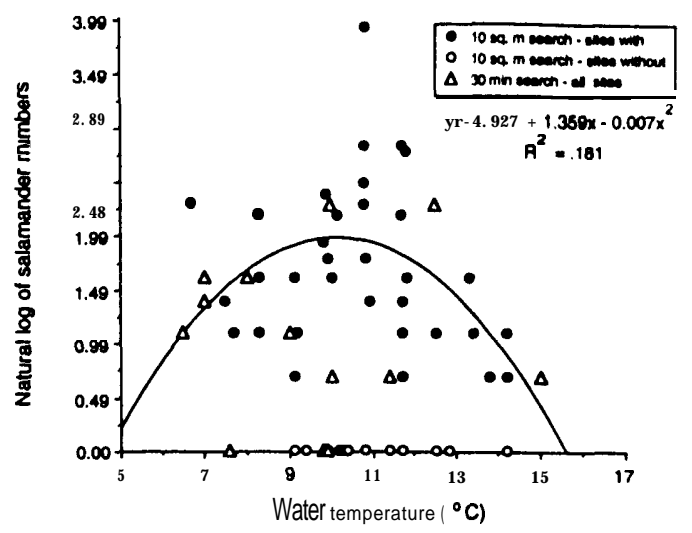

Fig. 4. Bivariate scatterplot of water temperature and the natural log of southern torrent salamander (Rhyacotriton variegatus) numbers/ $10 \mathrm{~m}^{2}$. Regression line and $\mathbf{R}^{2}$ pertain to those sites with salamanders from $10 \mathrm{~m}^{2}$ sample plots only (this study). Thirty minute search data (open triangles) are presented to show consistency in range of water temperatures (for methods on the thirty minute-search data see Welsh, 1990). Some overlapping points are obscured.

ter velocity at the exact spot where these small salamanders occur without disturbing the site and influencing the measurement; our measurements probably were too gross. However, we believe that based on their demonstrated association with seep microhabitat (Table 4, Fig. 2a), relatively low current speeds and shallow water are important attributes of $\mathrm{R}$. vuriegutus microhabitat.

The Grinnellian Niche of Rhyacotriton variegatus.--Our analysis of the niche (sensu Grinnell; see James et al., 1984) of R. variegatus in northwestern California, while consistent with earlier accounts, adds more detail and refinement than previous studies, and places the habitat components in an explicit spatial hierarchy. In addition, this analysis quantifies habitat attributes and confirms the importance of late seral attributes indicated by several recent studies (Welsh and Lind, 1988; Corn and Bury, 1989; Welsh, 1990; Bury et al. 1991). While it is clear that this species occurs in some early seral habitats (Diller and Wallace, 1996; this paper), its combined habitat preferences demonstrate an ecological dependence (Ruggiero et al., 1988) on conditions typically found in late seral forests. The macrohabitat (forest stand) and microhabitat (aquatic habitat) conditions evidenced here for R. vuriegutus are characteristic of lotic systems found primarily in closed-canopy, complex-structured, older forests. The complex structure, deep litter layer, and abundant downed woody debris of late seral forests equate 
TABLE 5. Suitable habitat model for the southern torrent salamander (Rhyacotriton variegatus).

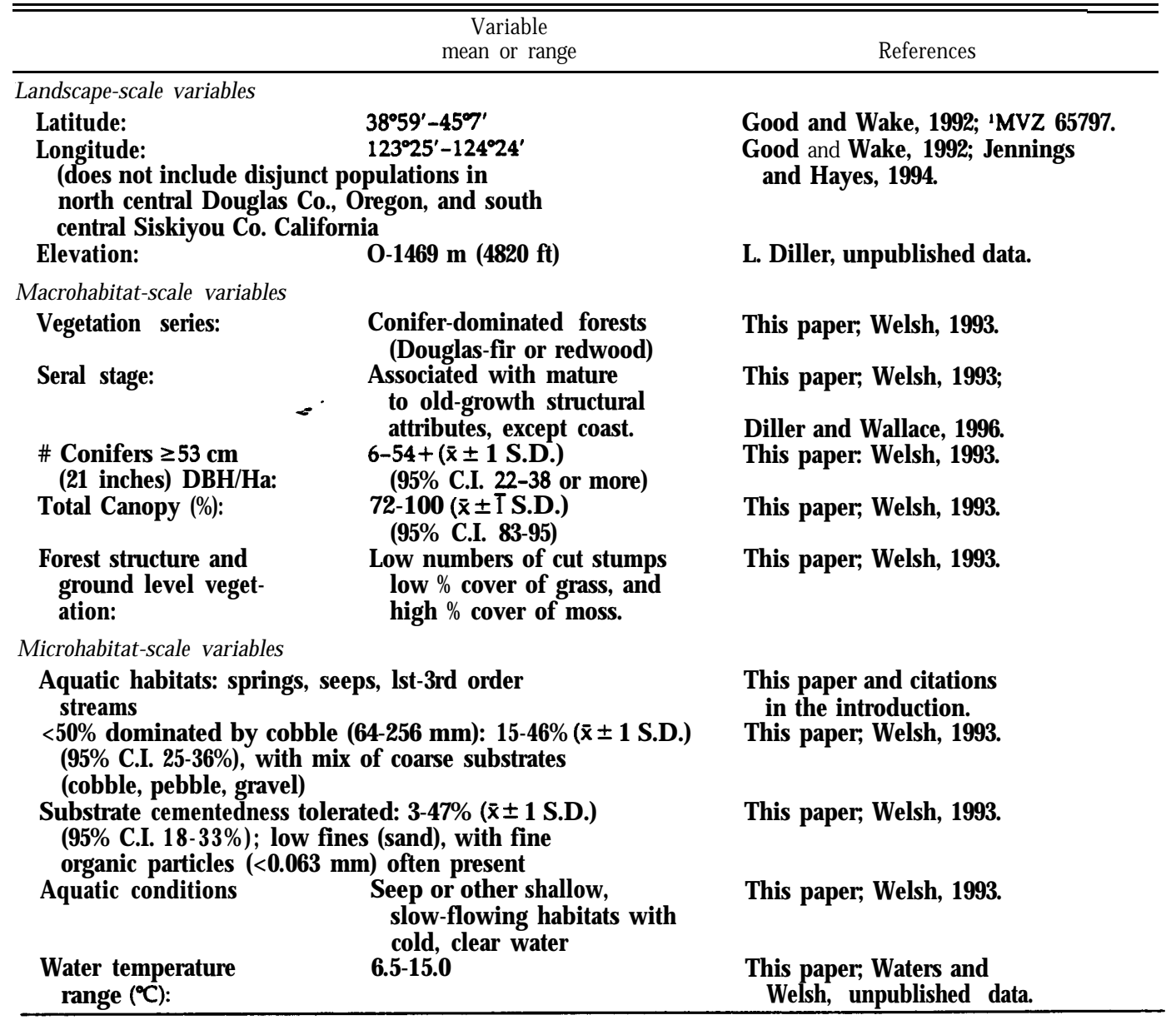

'Museum of Vertebrate Zoology, University of California, Berkeley.

directly to greater terrestrial and aquatic microhabitat complexity (Sedell and Swanson, 1984; ..Harmon et al., 1986; Bisson et al., 1986). The deep duff layer and decomposing wood also store and filter precipitation and help maintain lower stream temperatures and a cool, moist, and stable forest floor and streamside microclimate in these older forests (Brown and Krygier, 1970; Beschta et al., 1987; M aser et al., 1988; Chen et al., 1993a). We summarize the niche of $R$. variegatus in a multi-scaled, suitable habitat model (Table 5). This model has practical application as a tool to discern potential habitat (see Morrison et al. 1992). It can be used by forestland owners and resource managers, within the range of this species, who wish to make informed land management decisions that will maintain functional populations (Conner,
1988) of this highly specialized salamander on the lands in their care.

Forest $M$ anagement Considerations.-Diller and Wallace (1996) reported R. variegatus presence on harvested, commercial, redwood and D ouglas-fir forestlands in coastal areas of northern Humboldt, and Del Norte Counties in northern California. They reported a density of $0.28 / \mathrm{m}^{2}$ (range $=0.09$ to $5.0 / \mathrm{m}^{2} ; \mathrm{N}=14$ ) from random streams with known populations. In our comparable sampling from across most of the range in California, we found a mean density of $0.68 / \mathrm{m}^{2}$ (SD $=0.889 / \mathrm{m}^{2} ;$ range 0.1 to $5.0 / \mathrm{m}^{2} ; \mathrm{N}$ $=33$ ). Both studies lacked pre-harvest data so it is not possible to establish whether the lower relative densities on commercial forestlands are the result of harvesting.

Diller and Wallace (1996) reported significant 
relationships between $\mathrm{R}$. uariegatus presence and stream gradient, aspect, and geologic type (consolidated vs. unconsolidated). We found no concurrence in our analyses with slope or aspect. We also believe that Diller and Wallace's analysis of geology was not done at an appropriate scale. Landscape scale maps of geology do not depict unique small-scale lithologies. These salamanders can occur in relatively small patches of habitat that may be within, but different from, the gross geologic map units. In any event, we interpret Diller and Wallace's relationships with stream gradient, aspect, and geologic type, to be the result of logging, and evidence of its negative impacts on populations of this salamander. High gradient streams, those on north-facing slopes, and those on less erosive geologic types, would be more likely to sustain populations of $\mathrm{R}$. uariegatus post-harvest, compared with streams on low gradients, southfacing slopes, or unconsolidated geologies, because of differences in characteristics of sediment transport and microclimate (e.g., Corn and Bury, 1989). While R. vuriegutus clearly still occurs on private timberlands in the north coastal zone, Diller and Wallace (1996) noted that this species has been impacted in their study area by alterations to low gradient stream reaches and possibly to springs and seeps. Our study, with a proponderance of interior sites, indicated that logging impacts are probably more pronounced in interior areas which lack the ameliorating effects of the mild coastal climate. Data from coastal areas further south (southern Humboldt and Mendocino counties) indicate that such ameliorating effects may not be sufficient to maintain populations post-harvest in those areas (Welsh, unpubl. data; Brode, 1995).

Diller and Wallace (1996) also suggest that the presence of R. variegatus across their study area is evidence that current California forest practice rules provide adequate protection for this species on coastal forestlands in Humboldt -and Del Norte counties. We believe that the inverse relationship they report with forest age and the presence of $R$. vuriegutus suggests that past forestry practices were more detrimental to this species than are current practices. However, Diller and Wallace (1996) did not directly study or test the effects of current forestry practices relative to past practices. We believe that some recent California forest practice rule changes have improved riparian protections over the past. However, there still exists a serious problem with the misclassification of streams. This occurs when there is a faulty assumption made that aquatic life does not exist in a particular channel, and inadequate protections are then applied. Even when properly applied, the current rules may still be inadequate because the required watercoarse protection zone width for typical headwater habitats is very narrow (15 m) and may not maintain appropriate microclimate, especially at interior sites. Also this zone is not designated as a "no harvest" area but is only an equipment exclusion zone, allowing the removal of up to $50 \%$ of the canopy. In addition, the current rules are open to interpretation, such that the canopy can be reduced to $50 \%$ of pre-harvest canopy after each entry, so multiple entries along a stream will leave less canopy each time. We believe the California State Board of Forestry is remiss in not providing strong protection and enforcement for headwater habitats in order to protect this sal amander and other affected aquatic communities downstream (cf. Vannote et al., 1980).

A cknowledgments.-- We wish to thank Lisa Ollivier, Dana Waters, Dori Bojesson, Gary Perlmutter, and Anders Mikkelson for their help with the field work. James A. Baldwin, Jerry Allen, and Barry R. Noon advised us on statistical methods. We thank Lowell Diller, Norm Scott, Lisa Ollivier, and three anonymous reviewers for providing helpful comments on earlier drafts. We thank the California Department of Forestry and Fire Prevention and the USDA Forest Service for partial funding of this research. We are most grateful to Barry R. Noon, Michael J. Morrison, Don C. Erman, William F. Laudenslayer, Harry W. Greene, and Sharyn B. Marks for their encouragement, support, and advice. This paper is based on a dissertation submitted by the senior author as partial fulfillment of the requirements for a Ph.D. degree in the Department of Environmental Science, Policy, and Management, University of California, Berkeley.

\section{LITERATURE CITED}

Anderson, J. D. 1968. Rhyacotriton and R. olympicus. Catalogue of American Amphibians and Reptiles 68.1-68.2.

BESCHTA, R. L., R. E. BILBY, G. W. Brown, L. B. HOLTBY, AND T. D. HOFSTRA, 1987. Stream temperature and aquatic habitat: fisheries and forestry interactions. In E. Salo and T. Cundy (eds.), Streamside $M$ anagement: Forestry and Fishery Interactions, pp. 199-232. Proc. Sympos., Inst. of Forest Resources, Contrib. 57, Univ. Washington, Seattle.

BINGHAM, B. B., AND J. O. SA WYER, JR. 1991. DistinCtive features and definitions of young, mature, and old-growth D ouglas-fir/ hardwood forests. In L. Ruggiero, K. A ubry, A. Carey and M. H uff (tech. coords.), Wildlife and Vegetation of Unmanaged Douglas-fir Forests, pp. 362-377. USDA Forest Service Gen. Tech. Rpt. PNW-GTR-285, Pacific NW. Station, Portland, Oregon.

BISSON, P. A., R. E. BILby, M. D. BRyANt, C. A. DOLLOFF, G. B. GRETTE, R. A. H O USE, M. L. M UR PHY, K. V. KOSKI, ANd J. R. Sedell. 1986. Large woody de- 
bris in forested streams in the Pacific Northwest: past, present, and future. In E. Salo and T. Cundy (eds.), Streamside Managmement: Forestry and Fishery Interactions, pp. 143-190. Proc. Sympos., Inst. of Forest Resources, Contrib. 57, Univ. Washington, Seattle.

BRATTSTROM, B. H. 1963. A preliminary review of the thermal requirements of amphibians. Ecology 44 238-255.

BRAUN-BLANQUET, J. 1932. Plant Sociology; The Study of Plant Communities. McGraw-Hill, New York.

BRODE, J. M. 1995. Status review of the southern torrent salamander (R hyucotriton variegatus) in California. California Dept. Fish and Game, Rancho Cordova, California.

BRown, G. H., AND J. T. KRYGIER. 1970. Effects of clearcutting on stream temperature. Water Resour. Res. 6:1133-1 139.

Bury, R. B. 1970. Food similarities in the tailed frog A scaphus truei, and the Olympic salamander, Rhyacotriton olympicus. Copeia 1970:170-171.

BURY, R. B. 1988. Habitat relationships and ecological importance of amphibians and reptiles. In K. Raedeke (ed.), Streamside Management: Riparian Wildlife and Forestry Interactions, pp. 61-76. Institute of Forest Resources, Cont. No. 59. University of Washington, Seattle.

Bury, R. B., AND P. S. CORN. 1988. Responses of aquatic and streamside amphibians to timber harvest: a review. In K. Raedeke (ed.), Streamside Management: Riparian Wildlife and Forestry Interactions, pp. 165-181. Institute of Forest Resources, Cont. No. 59. University of Washington, Seattle.

Bury, R. B., AND P. S. CoRn. 1991. Sampling methods for amphibians in streams in the Pacific Northwest. USDA Forest Service Gen. Tech. Rep. PNWGTR-275, Pacific N orthwest Station, Portland, Oregon.

Bury, R. B., P. S. Corn, K. B. Aubry, F. F. Gilbert, AND L. C. JONES. 1991. Aquatic amphibian communities in Oregon and Washington. In L. Ruggiero, K. Aubry, A. Carey, and M. Huff (tech. coords.), Wildlife and Vegetation of Unmanaged Douglas-fir Forests, pp. 362-377. USDA Forest Service Gen. Tech. Rpt. PNW-GTR-285, Pacific NW. Station, Portland, Oregon.

CHEN, J., J. F. FrankLIN, AND T. A. Spies. 1993a. Contrasting microclimates among clearcut, edge, and interior of old-growth Douglas-fir forest. Agric. For. Meteorol. 63:219-237.

-----, J. F. FrankLIN, ANd T. A. Spies. 1993b. An empirical model for predicting diurnal air-temperature gradients from edge into old-growth Douglas-fir forest. Ecol. Model. 67:179-198.

CONNER, R. N. 1988. Wildlife populations: minimally viable or ecologically functional. Wildlife Soc. Bull. 16:80-84.

CoRn, P. S., AND R. B. BURY. 1989. Logging in western Oregon: responses of headwater habitats and stream amphibians. For. Ecol. \& M gmt. 29:39-57.

Diller, L. V., AND R. L. W ALLACE. 1996. Distribution and habitat of Rhyucotriton variegatus on managed, young growth forests in north coastal California. J. Herpetol. 30:184-191.

Federal Register. 1995. Endangered and threatened wildlife and plants; 90 day finding for a petition to list the southern torrent salamander. 60(125): 33785-33786.

Frank, E. C., And R. LeE. 1966. Potential solar beam irradiation on slopes: tables for $30^{\circ}$ to $50^{\circ}$ latitudes. USDA Forest Service Res. Pap. RM-18. Rocky Mt. Research Station, Ft. Collins, Colorado.

GOOD, D. A., AND D. B. WAKE. 1992. Geographic variation and speciation in the torrent salamanders of the genus R hyucotriton (Caudata; Rhyacotritonidae). Univ. California Publ. 2001. 126.

harmon, M. E., J. F. Franklin, F. J. Swanson, P. SO LLIN D, S. V. GREGORY, J. D. LATTIN<N. H. ANDERSON, S. P. CLINE, N. G. AUMEN, J. R. SEDELL< G. W. LIENKAEMPER, K Cromack, JR., AND K. W. Cummins. 1986. Ecology of coarse woody debris in temperate ecosystems. Advan. Ecol. Res. 15:133302.

JAEGER, R. G., AND R. F. I n CER. 1994. Quadrat sampling. In W. R. Heyer, M. A. Donelly, R. W. McDiarmid, L. C. Hayek, and M. S. Foster (eds.), Measuring and Monitoring Biological Diversity. Standard Methods for Amphibians, pp. 97-102. Smithsonian Institution Press, Washington D.C.

James, F. C., R. F. JOHnston, N. 0. WAMER, G. J. NiEmI, AND W. J. BOECKLEN. 1984. The Grinnelian niche of the wood thrush. Amer. Natur. 124:17-47.

JAMES, F. C., AND C. E. MCCulloch. 1990. Multivariate analysis in ecology and systematics: panacea or Pandora's box. Ann. Rev. Ecol. Syst. 21: 129-166.

Jennings, M. R., And M. P. Hayes. 1994. Amphibian and reptile species of special concern in California. California Dept. Fish and Game, Rancho Cordova, California.

JoHnSON, D. E. 1981. How to measure habitat-a statistical approach. In D. Capen (ed.), The use of Multivariate Statistics in Studies of Wildlife Habitat, pp. 53-57. USDA Forest Service, Gen. Tech. Rpt. RM-87, Rocky Mountain Research Station, Ft. Collins, Colorado.

Leonard, W. P., H. A. Brown, L. L. C. Jones, K. R. MCAllister and R. M. Storm. 1993. Amphibians of Washington and Oregon. Seattle Audubon Society, Seattle, Washington.

M a Ser, C., R. T. Tarrant, J. M. Trappe, and J. F. FrANKLIN (tech. eds.). 1988. From the Forest to the Sea: a Story of Fallen Trees. USDA Forest Service, Gen. Tech. Rpt. PNW-GTR-229. Pacific NW Research Station, Portland, Oregon.

McCain, M. D. Fuller, L. Decker, and C. Overton. 1990. Stream Habitat Classification and Inventory Procedures for Northern California. FHR Currents, Fish Habitat Relationships Tech. Bull. 1. Six Rivers Natl. Forest, Eureka, California.

Meehan, W. R., F. J. SWANSON, AND J. R. Sedell. 1977. Influences of Riparian Vegetation on Aquatic Ecosystems with Particular Reference to Salmonid Fishes and Their Food Supply. USDA Forest Service Gen. Tech. Rpt. RM-43:137-145. Rocky Mt. Experiment Station, Ft. Collins, Colorado.

MEYER, J. L., W. H. MCDOWELL, T. L. BOTT, J. W. ELWOOD, C. Ishizaki, J. M. Melack, B. L. Peckarsky, B. J. Peterson, And P. A. Rublee. 1988. Elemental dynamics in streams. J. N. Am. Benthol. Soc. 7:410432. 
Morrison, M. L., B. G. Marcot, and R. W. Mannan. 1992. Wildlife Habitat Relationships. Univ. Wisconsin Press, Madison.

Nussbaum, R. A. 1969. The nest site of the Olympic salamander, Rhyacotriton olympicus. Herpetologica 25:277-278.

$\longrightarrow$ AND C. A. TAIr. 1977. Aspects of the life history and ecology of the Olympic salamander, Rhyacotriton olympicus (Caige). Amer. Midl. Natur. 98:176-199.

—, E. D. Brodie, AND R. M. STorm. 1983. A mphibians and Reptiles of the Pacific Northwest. Univ. Idaho Press, Moscow.

PARKER, M. S. 1991. Relationship between cover availability and larval Pacific giant salamander density. J. Herpetol. 25:355-357.

Platts, W. S., W. F. Megahan, AND G. W. Minshall. 1983. Methods for Evaluating Stream, Riparian, and Biotic Conditions. USDA Forest Service GTR INT-138. Intermountain Experiment Station, Ogden, Utah.

RAY, C. 1958. Vital limits and rates of desiccation in salamanders. Ecology 39:75-83.

ReNCHER, A. C. 1992. Interpretation of canonical discriminant functions, canonical variates, and principal components. Amer. Stat. 46:217-225.

Ruggiero, L. F., R. S. Holthausen, B. G. Marcot, K. B. Aubry, J. W. Thomas, and E. C. Meslow. 1988. Ecological dependency: the concept and its implications for research and management. Trans. 53rd N. Amer. Wildl. and Nat. Res. Conf:115-126.

SAS IN STITUTE, INC. 1990. SAS User's Guide. Cary, North Carolina.

Sedell, J. R., and F. J. Swanson. 1984. Ecological characteristics of streams in old-growth forests of the Pacific Northwest. In W. Meehan, T. Merrell, Jr., and T. Hanley (eds.), Proceedings, Fish and Wildlife Relationships in Old-growth Forests Symposium., pp. 9-16. Amer. Inst. Fish. Research Biologists, Ashville, North Carolina.

SillverMaN, B. W. 1986. Density Estimation for Statistics and Data A nalysis. M onographs on Statistics and Applied Probability. Chapman and Hall, New York.

SoKAL, R. R., AND F. J. Rohlf. 1981. Biometry. W. H. Freeman and Co., San Francisco, California.

Stebbins, R. C. 1953. Southern occurrence of the Olympic salamander, Rhyacotriton olympicus. Herpetologica 11:238-239.

Strbbins, R. C. 1985. A Field Guide to Western Reptiles and Amphibians. Houghton Mifflin Company, Boston, Massachusetts.

Trtus, K., J. A. Mosher, AND B. K. Willuams. 1984. Chance-corrected classification for use in discriminant analysis: ecological applications. Amer. Midl. Natur. 111:1-7.
Thomas, J. W., L. F. Rucciero, R. W. MaNNaN, J. W. SCHOEN, AND R. A. LANCLA. 1988. Management and conservation of old-growth forests in the United States. Wildlife Soc. Bull. 16:252-262.

ToFt, C. A. 1991. Reply to Seaman and Jaeger: an appeal to common sense. Points of view: a controversy in statistical ecology. Herpetologica 46: 357-361.

Vannote, R. L., C. W. Minshall, K. W. Cummins, J. R. Sedell, and C. E. Cushing. 1980. The river continuum concept. Can. J. Fish. and Aqua. Sci. 37:130-137.

WATERS, W. E., AND D. C. ERman. 1990. Methods for Fish Biology. American Fisheries Society, Bethesda, Maryland.

WeLSH, H. H., JR. 1987. Monitoring herpetofauna in woodland habitats of N orthwestern California and southwestern Oregon: a comprehensive strategy. In T. Plumb and N. Pillsbury (eds.), Multiple-use Management of California's Hardwood Resources, pp. 203-213. USDA Forest Service Gen. Tech. Rpt. PSW-100, Pacific Southwest Station, Berkeley, CA.

WELSH, H. H., JR. 1990. Relictual amphibians and old-growth forests. Conserv. Biol. 4:309-319.

- 1993. A hierarchical analysis of the niche relationships of four amphibians of forested habitats of Northwestern California. Unpubl. Ph.D. Diss., Univ. California, Berkeley.

—_ 1994. Bioregions: an ecological and evolutionary perspective and a proposal for California. California Fish and Game 80:97-124.

— AND A. J. LiND. 1988. Old-growth forests and the distribution of the terrestrial herpetofauna. In R. Szaro, K. Severson, and D. Patton (tech. coords.), Management of Amphibians, Reptiles, and Small Mammals in North America, pp. 439-458. USDA Forest Service Gen. Tech. Rpt. RM-166. Rocky Mountain Experiment Station, Ft. Collins, Colorado.

- AND —. 1992. Population ecology of two relictual salamanders from the Klamath Mountains of northwestern California. In D. MCCullough and R. Barrett (eds.), Wildlife 2001:Populations, pp. 419-437. Elsevier Science Publishers, Ltd., London.

_ AND 1995 . Habitat correlates of the Del Norte salamander, Plethodon elongatus (Caudata: Plethodontidae), in northwestern California. J. Herpetol. 29:198-210.

WiENS, J. A. 1989. Spatial scale in ecology. Funct. Ecol. 1989:385-397.

Accepted: 1 May 1996. 